目 次

連載企画 対称性と群論

2. 空間群のヒエラルキーと分類

ネスポロ マッシモ・

51

総合報告

放射光 X線結晶構造解析による光合成・光化学系 II の

水分解・酸素発生機構の解明

神谷信夫, 沈 建仁. 64

放射光粉末結晶構造解析法を用いた多孔性配位高分子の

ガス吸着現象の構造科学的解明

久保田佳基 - 72

生体エネルギー変換にかかわる生体超分子複合体の構造研究

栗栖源嗣 ․ 81

解説

タンパク質の電子線三次元結晶構造解析と電荷の精密化

米倉功治, 眞木さおり ․ 88

最近の研究から

リボソーム由来ペプチドの $\mathrm{N}$ 末端をキャッピングする

新規ペプチドリガーゼの構造基盤

松井 崇. 96

光活性化アデニル酸シクラーゼ合成酵素 OaPACの

活性化機構解明

大木規央, 朴 三用 $\cdots 102$

受精にかかわる精子融合因子IZUMO1 と卵子受容体JUNOの

認識機構の解明

石田英子, 大戸梅治, 清水敏之 $\cdots 108$

POMGnT1の構造解析による筋ジストロフィー疾患発症機序解明

桑原直之, 加藤龍一, 萬谷 博, 遠藤玉夫 $\cdots 114$

コヒーシンローダーScc2のX線結晶構造解析

菊池壮太郎, Hongtao YU 121 


\section{目次}

新刊紹介

木村宏之・ 127

クリスタリット

Quintet状態, 電気四重極子相互,

久保田佳基 - 128

電子線二次元結晶構造胜枌 米倉功治 $\cdot 128$

ペプチド系抗生物質, 非リボソーム系ペプチド合成酵素,

ATP grasp モチーフ …………………………………………………松井＼cjkstart崇・・ 128

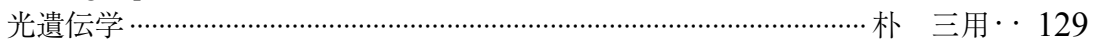

哺乳類細胞発現系……………………………………………………………桑原直之 ․ 129

コヒーシン, コヒーシンローダー, コヒーシンリリーサー………菊池壮太郎 ‥129

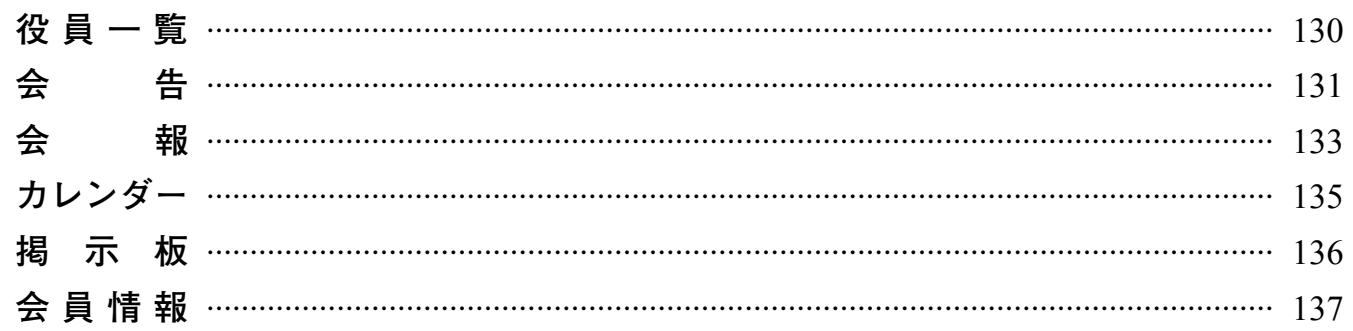

日本結晶学会誌電子版のご利用について

本誌は，創刊号から最新号まで電子化され，J-Stage http://www.jstage.jst.go.jp/browse/jcrsj/-char/ja/ で公開されており, 自由に閲覧可能です。本誌は, 日本結晶学会ホームページhttp://www.crsj.jpから リンクされています。

- Cover image for this issue (表紙)

膜タンパク質の三次元結晶の電子線回折パターン (a) と X 線

回折パターン (b)

(a)，(b)ともほぼ同じ条件で得られた膜タンパク質の結晶か ら測定.（a) 図 1 (a)の微小な平板結晶に $300 \mathrm{kV}$ の電子線を照 射して記録された回折パターン(眞木ら, 未発表). $2 \AA$ 前半 の分解能の回折点が観察される。(b) $100 \mu \mathrm{m}$ 程度の平板結晶 の一部分から, SPring-8のBL32XUにおいて波長 $1 \AA$ のX線 を照射して得られた回折パターン(眞木ら，未発表）。 Ewald 球曲面上に回折点が並んでいるのがわかる。（b）で用いた大 きく良質な結晶より，（a）の微小な結晶のほうがはるかに容 易に作製できる。
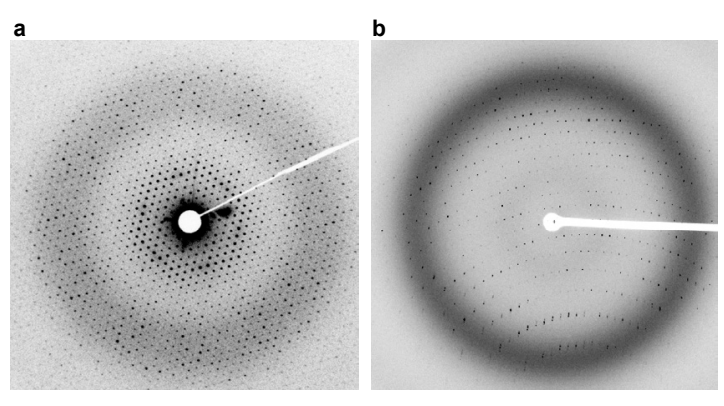

[米倉功治氏より提供, 本誌pp.88-95 参照] 


\title{
JOURNAL OF THE CRYSTALLOGRAPHIC SOCIETY OF JAPAN
}

\author{
Volume 59, Number $2 \cdot 3,2017$
}

\section{CONTENTS}

Introduction to Symmetry and Group Theory

2. Hierarchy and Classification of Space Groups

Massimo NESPOLO *

\section{Review Articles}

Elucidation of the Mechanism of the Water-Splitting and Oxygen-Evolving Reactionof

Photosystem II in Photosynthesis by X-Ray Crystal Structure Analysis Using Synchrotron

Radiation

-Nobuo KAMIYA and Jian-Ren SHEN •

Structural Study on the Gas Adsorption Phenomena in Porous Coordination Polymers by

Synchrotron Powder Diffraction Method

Yoshiki KUBOTA .

Structural Studies of Supramolecular Complexes for Energy Transduction in Biological Systems

Genji KURISU ·

\section{Articles}

Electron 3D Crystallography of Protein Structures and Refinement of Charges

..Koji YONEKURA and Saori MAKI-YONEKURA *

Structural Basis for the N-Terminal Capping onto the Ribosomal Peptide by Novel Peptide

Ligase PGM1

Takashi MATSUI • . 96

Structural and Functional Insights into a Photoactivated Adenylyl Cyclase

Mio OHKI and Sam-Yong PARK · 102

Structure of IZUMO1-JUNO Reveals Sperm-Oocyte Recognition during Mammalian Fertilization

Hanako ISHIDA, Umeharu OHTO and Toshiyuki SHIMIZU • 108

Mechanism for the Deficiency in Post-Phosphoryl Modification of $\alpha$-Dystroglycan

Observed in POMGnT1-Caused Muscular Dystrophy

..Naoyuki KUWABARA, Ryuichi KATO, Hiroshi MANYA and Tamao ENDO * 114

Crystal Structure of the Cohesin Loader Scc2

Published by

The Crystallographic Society of Japan

358-5 Yamabukicho, Shinjuku-ku,

Tokyo 162-0801, Japan 


\title{
JOURNAL OF THE CRYSTALLOGRAPHIC SOCIETY OF JAPAN
}

\author{
Volume 59, Number 2·3, 2017
}

\section{CONTENTS}

\section{Book Review}

\section{Crystallite}

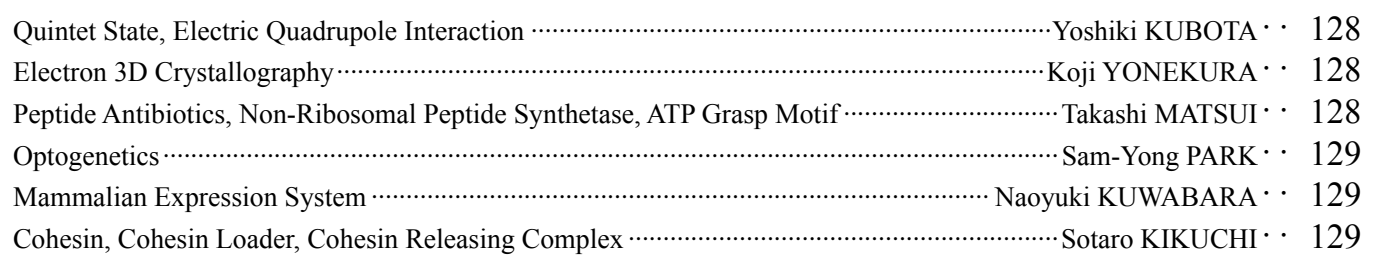

\section{CrSJ News}

\section{Electronic Version of the Journal of the Crystallographic Society of Japan}

All the issues of the journal are available on J-Stage http://www.jstage.jst.go.jp/browse/jcrsj. All contents of the issues published can be accessed freely. The journal page is linked from the web page of the Crystallographic Society of Japan http://www.crsj.jp.

Published by

The Crystallographic Society of Japan 358-5 Yamabukicho, Shinjuku-ku, Tokyo 162-0801, Japan 